\title{
Stenotrophomonas Maltophilia Peritonitis in a Child: Case Report and Review of the Literature
}

\author{
Bir Çocuk Olguda Stenotrophomonas Maltofilia \\ Peritoniti: Olgu Sunumu ve Literatür Derlemesi
}

Olgu Sunumu Case Report

Received/Geliş: 12.07.2019 Accepted/Kabul: 07.10.2019 Published Online: 05.01.2021

\section{$\overline{ }$ \\ Demet Alaygut Tepecik Eğitim ve Araştırma Hastanesi Çocuk Nefroloji Kliniği, İzmir - Türkiye alaygutdemet@gmail.com ORCID: 0000-0002-2164-4652}

C. Alparslan 0000-0002-7046-8907 O. Yavaşcan 0000-0002-3582-5075 F. Mutlubaş 0000-0001-9392-4832 B. Kasap-Demir 0000-0002-5456-3509 Tepecik Eğitim ve Araştırma Hastanesi Çocuk Nefroloji Kliniği, izmir, Türkiye

S. Sarıtaş 0000-0002-3236-4285 E.P. Öncel 0000-0002-6126-4048 Tepecik Eğitim ve Araştırma Hastanesi Çocuk Sağlığı ve Hastalıkları, izmir, Türkiye

Cite as: Alaygut D, Alparslan C, Sarıtaş S, et al. Stenotrophomonas maltophilia peritonitis in a child: Case report and review of the literature. Tepecik Eğit. ve Araşt. Hast. Dergisi. 2020;30(3):316-21.

\author{
Demet Alaygut $\oplus^{\oplus}$, Caner Alparslan ${ }^{\oplus}$, Serdar Sarıtaş ${ }^{\oplus}$, Elif Perihan Öncel $\oplus^{\bullet}$

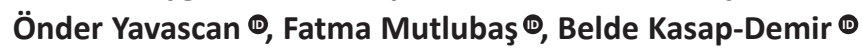

\begin{abstract}
Stenotrophomonas maltophilia peritonitis has been only occasionally reported in patients undergoing continuous ambulatory peritoneal dialysis (CAPD). Because this microorganism has multi-drug resistance, its treatment is hard and long-term. The treatment might not be successful despite all the efforts and the process of peritoneal dialysis , and may terminate with loss of the catheter. In the present paper, S. maltophilia peritonitis developed in a 6-yearold girl patient, who underwent peritoneal dialysis due to bilateral dysplastic kidney, suffered from episodes of peritonitis frequently and required hospitalization, was presented with literature data. Even though the case received multiple antibiotic treatment and underwent endoluminal brushing (EB), the success of treatment could not be achieved. To the best of our knowledge, this patient is the youngest case in the literature.
\end{abstract}

Keywords: Stenotrophomonas maltophilia, peritonitis, child

öz

Stenotrophomonas maltophilia peritoniti, sürekli ayaktan periton diyalizi (SAPD) geçiren hastalarda nadiren bildirilmiştir. Mikroorganizma çoklu ilaç direncine sahip olduğu için tedavisi uzun ve zordur. Tüm çabalara ve periton diyalizi sürecine rağmen tedavi başarıı olmayabilir, kateter kaybı ile sona erebilir. Bu yazıda, bilateral displastik böbrek nedeniyle periton diyalizi uygulayan, peritonit ataklarından sıkıntı çeken ve hastaneye yatırılan 6 yaşındaki bir kız hastada gelişen S. maltophilia peritoniti, literatür verileri ile sunuldu. Olguya çoklu antibiyotik tedavisi uygulanmış ve endolüminal fırçalama (EB) yapılmış olmasına rağmen tedavinin başarısı sağlanamamıştır. Bildiğimiz kadarılya, bu hasta literatürdeki en genç vakadır.

Anahtar kelimeler: Stenotrophomonas maltophilia, peritonit, çocuk

\section{INTRODUCTION}

Stenotrophomonas maltophilia (S. maltophilia) an opportunistic pathogen is a free living, motile, aerobic, oxidase-negative, glucose nonfermentative, gram-negative, multidrug-resistant bacillus prevalent particularly among inpatients ${ }^{(1)}$. It can be frequently isolated from water, earth, animals, plants, and hospital equipments ${ }^{(2)}$. S. maltophilia is the only one species of the genus
Stenotrophomonas which is known to infect humans. It was isolated from pleural fluid in 1943 by Edward for the first time and named as Bacterium brokeri ${ }^{(3,4)}$. Hugh and Ryschenkow reclassified and named it as Pseudomonas maltophilia in 1961. Twenty years later, Swings et al., named P. maltophilia as Xanthomonas maltophilia. Finally, Palleroni and Bradbury gave the last and up-to-date name, S. maltophilia, to the microorganism in 1993 (3). S. maltophilia leads to numerous

(c) Telif hakkı T.C. Sağık Bakanlığı İzmir Tepecik Eğit. ve Araşt. Hastanesi. Logos Tıp Yayıncılık tarafindan yayınlanmaktadır. Bu dergide yayınlanan bütün makaleler Creative Commons Attf-GayriTicari 4.0 Uluslararası Lisansı ile lisanslanmıştr.

(c) Copyright Association of Publication of the T.C. Ministry of Health İzmir Tepecik Education and Research Hospital. This journal published by Logos Medical Publishing. Licenced by Creative Commons Attribution-NonCommercial 4.0 International (CC BY) 
different infections such as bacteremia, endocarditis, respiratory tract infections, meningitis, urinary tract infections, skin and soft tissue infections, mastoiditis, bone and joint infections, peritonitis, typhlitis and biliary sepsis, wound infections, and central venous catheter-related infections in immunocompromised people ${ }^{(4)}$. Risk factors are considerably variable and Table 1 shows these risk factors ${ }^{(1)}$. S. maltophilia was previously reported to be the cause of both peritonitis and infections at the exit site in patients undergoing chronic peritoneal dialysis. This microorganism, which is resistant and hard to control via medical treatment, is substantially important because it may lead to catheter loss and paves the way for the growth of other opportunist microorganisms. In this paper, a 6-year-old child who underwent chronic peritoneal dialysis and had to start the hemodialysis program by losing peritoneal dialysis catheter because of $S$. maltophilia growth was presented with the literature data. To the best of our knowledge, this case is the youngest one in the literature.

Table 1. Risk factors for S. maltophilia infections.

Malignancy, particularly hematological malignancy

Human immunodeficiency virus (HIV)

Cystic fibrosis

Intravenous drug abuse

Surgical and accidental trauma

Prolonged hospitalization

Admission to ICU and mechanical ventilation

Vascular catheters and urinary catheters

Corticosteroids and immunsupressive therapy

Prior treatment with brod-spectrum antibiotics

Gastrointestinal tract colonization and mucositis

Hematopoietic stem cell transplantation

Travel to hospital by air

\section{CASE REPORT}

The 6-year-old girl patient who had the end-stage renal failure due to bilateral dysplastic kidney and was in peritoneal dialysis program (CAPD) for 2 years, was hospitalized in the service with prediagnosis of peritonitis upon lack of appetite, vomiting, stomach ache, fever, and cloudy dialysis fluid 3 days before her admission. From her history, it was found out that she was previously treated 5 times due to peritonitis and she had the last peritonitis 3 months previously. Some parametres measured were as follows: body weight: $12.9 \mathrm{~kg}(3 \mathrm{p})$, height: $90 \mathrm{~cm}(3 p)$, heart rate: $94 / \mathrm{min}$, respiratory rate: $20 /$ min, blood pressure: 129/100 (>95.p/>95.p) mmHg, and body temperature: $38^{\circ} \mathrm{C}$. Besides abdominal distension and sensitivity were detected on physical examination. Some biochemical values were as follows: white blood cell /WBC):13.100 U/L, C-reactive protein $164.7 \mathrm{mg} / \mathrm{L}$ (N: 0-5), procalcitonin $9.4 \mathrm{ng} / \mathrm{mL}$ (N:0-0.1), creatinine: $4.6 \mathrm{mg} / \mathrm{dL}$, urea:86 mg/dL, K $6.9 \mathrm{mg} / \mathrm{dL}$, and serum albumin $3.1 \mathrm{mg} / \mathrm{dl}$. Peritoneal fluid was cloudy and microscopic examination contained $>1000$ cell $/ \mathrm{mm}^{3}$. Empirical antibiotic treatment was initiated with intraperitoneal doses of cefazolin (loading dose: $500 \mathrm{mg} / \mathrm{L}$, and maintenance dose: $125 \mathrm{mg} / \mathrm{L}$ ) and ceftazidime (loading dose: $500 \mathrm{mg} / \mathrm{L}$, and maintenance dose: $125 \mathrm{mg} / \mathrm{L}$ ) before obtaining blood and peritoneal fluid cultures of the case. $S$. maltophilia grew in peritoneal fluid culture. Microorganism was sensitive to TMP-SMX, levofloxacin, and tigecycline, moderately sensitive to ceftazidime, and resistant to other antibiotics. Cefazolin treatment was terminated and trimethoprim- sulfamethaxazole (co-trimoxazole) was started at systemic renal dose $(5 \mathrm{mg} / \mathrm{kg} /$ day) , and intraperitoneally (TMP-SMX loading dose: 320/160 mg, maintenance dose: $80 / 400 \mathrm{mg}$ ). The case whose cell count was monitored daily underwent peritoneal endoluminal brushing process twice and cell count declined down to $20 / \mathrm{mm}^{3}$. However, the case was accepted to be resistant peritonitis because the same microorganism grew again in the culture of the control peritoneal fluid which was sent 2 more times while the patient was under treatment. Systemically administered TMP-SMX was stopped and levofloxacin $(8 \mathrm{mg} /$ $\mathrm{kg} /$ day) was started intravenously. Intraperitoneal ceftazidimeandTMP-SMX was continued. Fluconazole was also started as antifungal because of multiple antibiotic treatment. WBC was not identified in peritoneal fluid on the $5^{\text {th }}$ day of levofloxacin treatment. Thrombocytopenia developed on the $8^{\text {th }}$ day of treatment, and pancytopenia on the day 10 which were 
Table 2. Demographic and clinical characteristics of patients with Stenotrephomonas maltophilia infection (peritonitis and/ or exit site infection) in literature.

\begin{tabular}{|c|c|c|c|c|c|c|c|c|c|c|c|c|}
\hline $\begin{array}{l}\text { Patient } \\
\text { no }\end{array}$ & Age & Gender & RD & $\begin{array}{l}\mathrm{RF} / \mathrm{co}- \\
\text { morb. }\end{array}$ & $\begin{array}{l}\text { Period of } \\
\text { dialysis } \\
\text { (months) }\end{array}$ & $\begin{array}{l}\text { No of } \\
\text { previous } \\
\text { infection }\end{array}$ & $\begin{array}{l}\text { Time of } \\
\text { the last } \\
\text { infection }\end{array}$ & $\begin{array}{l}\text { Type of } \\
\text { infection }\end{array}$ & Treatment & $\begin{array}{l}\text { Infection } \\
\text { duration } \\
\text { (weeks) }\end{array}$ & Outcome & Ref. \\
\hline 1 & 61 & $\mathrm{~F}$ & DN & $\mathrm{Ml}$ & 32 & 3 & 20 mo.ago & $\mathrm{P}$ & $\begin{array}{l}\text { Cefaz (IP) + Tob(IP) } \\
\text { Ceft (IP) + Amk (IP) } \\
\text { Ceft (IP) + Amk (IP) + Pip (IV) }\end{array}$ & 23 & Catheter removal & Baek et al 5 \\
\hline 2 & 34 & $\mathrm{~F}$ & DN & $\mathrm{PH}$ & 24 & 1 & $18 \mathrm{mo}$ ago & $\mathrm{P}$ & Cefaz (IP) + Tob (IP) & 3 & Continued PD & Baek et al 5 \\
\hline 3 & 48 & $\mathrm{~F}$ & $\mathrm{DN}$ & No & 15 & 2 & 1 mo.ago & $\mathrm{P}$ & $\begin{array}{l}\text { Van (IP) + Ceft (IP)+Cipr (IP)+ } \\
\text { Tmp-Smx (IP) + Ceft (IP) } \\
\text { Amphotericin (IV) }\end{array}$ & 5 & $\begin{array}{l}\text { Catheter removal, } \\
\text { HD }\end{array}$ & \\
\hline 4 & 62 & $\mathrm{M}$ & RT & CVA & 12 & 0 & 7 mo.ago & ESI & Ceft(IV,IP) + Tob (IP) & 2 & Continued PD & Baek et al 5 \\
\hline 5 & 50 & $\mathrm{M}$ & No data & COPD & $\mathrm{CHF}$ & 5 & 23 mo.ago & ESI & $\begin{array}{l}\text { 1. } \operatorname{Cipr}(\mathrm{PO})+\operatorname{Cefac}(\mathrm{PO}) \\
\text { 2. } \operatorname{Cipr}(\mathrm{PO})+\operatorname{Amxccv}(\mathrm{PO})\end{array}$ & $\begin{array}{l}1^{\text {st }}: 2 \\
2^{\text {nd. }}: 2\end{array}$ & Continued PD & Baek et al 5 \\
\hline 6 & 54 & $\mathrm{~F}$ & Alport dis. & No & 23 & 0 & - & $\mathrm{P}$ & $\begin{array}{l}\text { Ceft (IP) + Van (IP) } \\
\text { Tmp-Smx (IP) + Amk (IP) }\end{array}$ & 2 & Continued PD & Baek et al 5 \\
\hline 7 & $\begin{array}{l}\text { No } \\
\text { data }\end{array}$ & $\begin{array}{l}\text { No } \\
\text { data }\end{array}$ & No data & No data & No data & 0 & - & $\mathrm{P}$ & $\begin{array}{l}\rightarrow \text { Van (IP) + Imip (IP) } \\
\rightarrow \text { Ceft (IP) + Gent (IP) } \\
\rightarrow \text { Cipr }\end{array}$ & No data & $\begin{array}{l}\text { Catheter } \\
\text { removal }\end{array}$ & Machuca E et al 21 \\
\hline 8 & $\begin{array}{l}\text { No } \\
\text { data }\end{array}$ & $\begin{array}{l}\text { No } \\
\text { data }\end{array}$ & No data & No data & No data & 1 & 8 wk. ago & $P$ & $\begin{array}{l}\text { Van (IP) + Imip (IP) } \\
\text { Ceft } \\
\text { Cipr } \\
\text { Tmp-Smx }\end{array}$ & No data & Catheter removal & Szeto et al 6 \\
\hline 9 & $\begin{array}{l}\text { No } \\
\text { data }\end{array}$ & $\begin{array}{l}\text { No } \\
\text { data }\end{array}$ & No data & No data & No data & 3 & 2 wk.ago & $\mathrm{P}$ & $\begin{array}{l}\text { Van (IP) + Imip (IP) } \\
\text { Ceft (IP) + Neti (IP) }\end{array}$ & No data & Catheter removal & Szeto et al 6 \\
\hline 10 & $\begin{array}{l}\text { No } \\
\text { data }\end{array}$ & $\begin{array}{l}\text { No } \\
\text { data }\end{array}$ & No data & No data & No data & 1 & 7 wk ago & $\mathrm{P}$ & $\begin{array}{l}\text { Van (IP) + Imip (IP) } \\
\text { Ceft (IP) } \\
\text { Cipr (IP) }\end{array}$ & No data & Catheter removal & Szeto et al 6 \\
\hline$\overline{11}$ & $\begin{array}{l}\text { No } \\
\text { data }\end{array}$ & $\begin{array}{l}\text { No } \\
\text { data }\end{array}$ & No data & No data & No data & 2 & 2 wk ago & $\mathrm{P}$ & $\begin{array}{l}\text { Van (IP) + Imip (IP) } \\
\text { Ceft (IP) + Neti (IP) }\end{array}$ & No data & Catheter removal & Szeto et al 6 \\
\hline$\overline{12}$ & $\begin{array}{l}\text { No } \\
\text { data }\end{array}$ & $\begin{array}{l}\text { No } \\
\text { data }\end{array}$ & No data & No data & No data & 0 & - & $\mathrm{P}$ & $\begin{array}{l}\text { Van (IP) + Imip (IP) } \\
\text { Ceft (IP) + Ampicillin (IP) }\end{array}$ & No data & Catheter removal & Szeto et al 6 \\
\hline$\overline{13}$ & 54 & $\mathrm{M}$ & $\begin{array}{l}\text { Calsineurine } \\
\text { toxitiy }\end{array}$ & No data & No data & No data & No data & $\mathrm{P}$ & $\begin{array}{l}\text { Van (IV) + Ceft (IP) } \\
\text { Tmx-Smx (IP) }\end{array}$ & No data & $\mathrm{HD}$ & Szeto et al 6 \\
\hline$\overline{14}$ & 57 & $\mathrm{~F}$ & DN & No & 36 & 0 & - & $P$ & $\begin{array}{l}\text { Van (IP) + Ceft (IP) } \\
\text { Ceft (IP) + Levofl (IP) }\end{array}$ & 2 & Continued PD & $\begin{array}{l}\text { Beatriz Millan- } \\
\text { Diaz et al } 12\end{array}$ \\
\hline$\overline{15}$ & 63 & $M$ & DN & No & 43 & 4 & No data & $\mathrm{P}$ & $\begin{array}{l}\text { Van (IP)+ Gent (IP) } \\
\text { Ceft (IP) + Cipro (IP) }\end{array}$ & No data & $\begin{array}{l}\text { Catheter } \\
\text { removal, } \mathrm{HD}\end{array}$ & Azak A etal 11 \\
\hline$\overline{16}$ & 65 & $\mathrm{~F}$ & DN & No & 19 & 2 & No data & $\mathrm{P}$ & $\begin{array}{l}\text { Van (IP) +Gent (IP) } \\
\text { Ceft (IP)+ Cipro (IP) }\end{array}$ & No data & $\begin{array}{l}\text { Catheter } \\
\text { removal, HD }\end{array}$ & N.Al-Hilali et al 13 \\
\hline$\overline{17}$ & 40 & $M$ & $\mathrm{DN}$ & No & 17 & 0 & - & ESI & Ceft (IP) + Amic (IP) & No data & $\begin{array}{l}\text { Replaced, } \\
\text { Continued PD }\end{array}$ & N. Al-Hilali et al 13 \\
\hline 18 & 56 & $\mathrm{M}$ & DN & No & 12 & 1 & No data & ESI & Tmp-Smx (oral) & No data & $\begin{array}{l}\text { Not replaced, } \\
\text { Continued PD }\end{array}$ & N. Al-Hilali et al 13 \\
\hline 19 & 35 & $\mathrm{~F}$ & No data & No data & 64 & No data & No data & ESI & Tmp-Smx (oral) & 30 day & Continued PD & N. Al-Hilali et al 13 \\
\hline 20 & 75 & $\mathrm{M}$ & No data & No data & 11 & No data & No data & $\mathrm{ESI}, \mathrm{P}$ & Parenteral antibiotic & 455 days & Catheter removal & Dapena F et al 8 \\
\hline 21 & 30 & $\mathrm{~F}$ & No data & No data & 20 & No data & No data & ESI & Tmp-Smx (oral) & 500 days & $\begin{array}{l}\text { Continued PD, } \\
\text { Granuloma }\end{array}$ & Dapena F et al 8 \\
\hline 22 & 37 & $\mathrm{M}$ & No data & No data & 59 & No data & No data & ESI & Tmp-Smx (oral) & 7 day & Continued PD & Dapena F et al 8 \\
\hline 23 & 39 & $\mathrm{M}$ & No data & No data & 53 & No data & No data & ESI & Tmp-Smx (oral) & 120 days & Continued PD & Dapena F et al 8 \\
\hline 24 & 36 & $\mathrm{~F}$ & No data & No data & 36 & No data & No data & ESI & Tmp-Smx (oral) & 7 day & Continued PD & Dapena F et al 8 \\
\hline 25 & 74 & $\mathrm{~F}$ & No data & No data & 32 & No data & No data & ESI & Tmp-Smx (oral) & 24 days & Continued PD & Dapena F et al 8 \\
\hline 26 & 39 & $\mathrm{M}$ & No data & No data & 8 & No data & No data & ESI & Parenteral antibiotics & 45 days & Continued PD & Dapena F et al 8 \\
\hline 27 & 60 & $\mathrm{M}$ & CPN & No data & 96 & Repeatedly & $12 \mathrm{mo}$ ago & $\mathrm{P}$ & Ceft (IP) + Tmp-Smx (IV) & 3 & Continued PD & Dapena F et al 8 \\
\hline 28 & 64 & $\mathrm{~F}$ & PKD & No data & 120 & 2 & $84 \mathrm{mo}$ ago & $P$ & $\begin{array}{l}\text { Ceft (IP) + Amc (IP) } \\
\text { Tmp-Smx (IV) }\end{array}$ & 6 & Continued PD & Tzanetou $\mathrm{K}$ et al 10 \\
\hline 29 & 64 & $\mathrm{~F}$ & CGN & No data & 96 & 0 & No data & $P$ & $\begin{array}{l}\text { Van (IP) + Ceft (IP) } \\
\text { Amc (IP)+Cipr (IV)+Tmp-Smx (IV) }\end{array}$ & No data & Continued PD & Tzanetou $\mathrm{K}$ et al 10 \\
\hline 30 & 40 & $\mathrm{M}$ & CGN & No data & 96 & 1 & No data & $\mathrm{P}$ & Tmp-Smx (IV) & No data & Continued PD & Tzanetou $\mathrm{K}$ et al 10 \\
\hline 31 & $\begin{array}{l}\text { No } \\
\text { data }\end{array}$ & $\begin{array}{l}\text { No } \\
\text { data }\end{array}$ & $\mathrm{N}$ & No data & 96 & 0 & No data & $\mathrm{P}$ & $\begin{array}{l}\text { Tmp-Smx (IV) + ticarcillin- } \\
\text { clavulonate (IV) }\end{array}$ & No data & $\begin{array}{l}\text { Cathetere } \\
\text { replacement }\end{array}$ & Tzanetou $\mathrm{K}$ et al 10 \\
\hline 32 & 61 & $\mathrm{M}$ & No data & No data & 60 & $1.6^{*}$ & No data & $\mathrm{P}$ & No data & No data & Continued PD & Tzanetou $\mathrm{K}$ et al 10 \\
\hline 33 & 64 & $\mathrm{M}$ & No data & No data & 9 & $1.3^{*}$ & No data & $\mathrm{P}$ & No data & No data & Continued PD & Taylor G et al 9 \\
\hline 34 & 52 & $\mathrm{~F}$ & No data & No data & 26 & $0.0^{*}$ & No data & $\mathrm{P}$ & No data & No data & Catheter removal & Taylor $\mathrm{G}$ et al 9 \\
\hline 35 & 19 & $\mathrm{~F}$ & No data & No data & 68 & $0.9^{*}$ & No data & $\mathrm{P}$ & No data & No data & Catheter removal & Taylor $\mathrm{G}$ et al 9 \\
\hline 36 & 16 & $\mathrm{~F}$ & No data & No data & 6 & $2.0^{*}$ & No data & $\mathrm{P}$ & No data & No data & Cathetere removal HD & Taylor $\mathrm{G}$ et al 9 \\
\hline 37 & 43 & $\mathrm{~F}$ & No data & No data & 99 & $0.7^{*}$ & No data & $\mathrm{P}$ & No data & No data & Continued PD & Taylor $\mathrm{G}$ et al 9 \\
\hline 38 & 16 & $M$ & No data & No data & 1 & $0.0^{*}$ & No data & $\mathrm{P}$ & No data & No data & $\begin{array}{l}\text { Cathetere removal, } \\
\text { renal failure resolved }\end{array}$ & Taylor $\mathrm{G}$ et al 9 \\
\hline $\begin{array}{l}\text { Our } \\
\text { case }\end{array}$ & 6 & $\mathrm{~F}$ & DK & $\mathrm{RH}$ & 26 & 5 & 3 & $\mathrm{P}$ & $\begin{array}{l}\text { Ceph (IP) + Ceft (IP) Tmp-Smx } \\
\text { (IP) + Ceft (IP) + Tmp-Smx (IV) } \\
\text { + endoluminal brushing (2 } \\
\text { times) Tmp-Smx (IP) + Ceft } \\
\text { (IP) + Levofloxacin (IV) }\end{array}$ & 4 & $\begin{array}{l}\text { Catheter removal, } \\
\text { HD }\end{array}$ & Taylor $\mathrm{G}$ et al 9 \\
\hline
\end{tabular}

Amk: Amikasin, Ceft: Ceftazidime, CVA: Cerebrovascular accident, COPD: Chronic obstructive pulmonary disease, CGN: Chronic glomerulonephritis, CHF: Congestive heart failure, DN: Diabetic nephropathy, DK: Dysplastic kidney, ESI: Exit-site infection, MI: Myocardial infarction, N: Nephrolithiazis, P: Peritonitis, PH: Panhypopituitarism, PKD: Polycystic kidney disease, RD: Renal disease, RH: Recurren hospitalization, RT: Renal tuberculosis, RF: Risk factors, Van: Vancomisin 
evaluated as the side effect of levofloxacin. Treatment was terminated. Bacterial growth was not observed in the culture of the control peritoneal fluid. Intraperitoneal treatment was completed within 21 days and then discontinued. The patient who re-applied to the clinic after 24 hours with the complaints of deteriorated general condition, widespread abdominal distension, vomiting, and high fever which were evaluated as being compatible with sepsis and peritonitis. Peritoneal fluid was cloudy and a gelatinlike structure was forming in a short time. In the microscopic examination $>1000 \mathrm{cell} / \mathrm{mm}^{3}$ were determined. Vancomycin, meropenem, and fluconazole were started systemically. Catheter was removed and hemodialysis treatment was started. The case was discharged after completion of systemic treatments within 21 days.

\section{DISCUSSION}

S. maltophilia has been continuing to confront us as a nasocomial pathogen with ever-increasing prevalence. It is more frequent especially in immunosuppressed individuals and Table 1 shows risk factors. Even though patients undergoing peritoneal dialysis were not listed in this table, both diseases leading to comorbidities in these people and negative effects of uremia on immune system make them risky. In their study, Baek et al. ${ }^{(5)}$ indicated that even though it was not statistically significant, serum albumin, hemoglobin, creatinine and BUN values of 5 patients were lower than those in other CAPD patients and uremia, malnutrition, and anemia were nonspecific suppressive factors of immune function. Our CAPD patient had malnutrition. Furthermore, she had additional risk factors as recent history of peritonitis, use of broad-spectrum antibiotic, and frequent hospitalizations. The last antibiotic treatment was the most important risk factor reported in occurrence of peritonitis ${ }^{(6)}$. Particularly, use of broad-spectrum antibiotics is a risk factor for the growth of opportunistic and multiple-drug resistant organisms. It is stated to occur when imipenem is used frequently ${ }^{(7)}$. The use of imipenem is not known because our case had been treated in another center previously. However, it was found out that she had peritonitis frequently and the last episode of peritonitis was experienced 3 months ago.

When we searched the literature with the key words: "S. maltophilia, Xanthomonas maltophilia and P. Maltophilia and peritonitis", we reached 38 cases with peritonitis and exit site infection (ESI) Age, gender, underlying renal disorders, risk factors, comorbid diseases, length of dialysis treatment (in months), the number of previous episodes of peritonitis, the time elapsed since the last peritonitis, the type of infection, treatments provided, duration of infection, and clinical results of the cases were reviewed and shown in Table 2. Firstly, our case was remarkable because she was the youngest one identified in the literature. The biggest patient series with 8 patients was reported by Dapena F et al., ${ }^{(8)}$ and they compared ESI associated with X. Maltophilia in 8 CAPD patients with ESI and 15 patients with P. Aeruginosa-associated ESI (Table 2 Patient no 19-26). One of these cases (No 20) had concurrent peritonitis. Except for two patients, oral TMP-SMX treatment was administered and no patients experienced catheter loss except for one. While the patient number 19 experienced 3 episodes, the patient number 25 experienced 4 episodes. When compared with pseudomonas-associated ESI, patients with $\mathrm{X}$. Maltophilia had a better prognosis.

The other large series with 7 patients was reported by Taylor $\mathrm{G}$ et al. ${ }^{\left({ }^{9}\right)}$. All of these patients had peritonitis. It was reported that two patients received an immunosuppressive treatment. One of these patients received immunosuppressive treatment due to cardiac transplantation, and the other one used cyclosporine due to Wegener granulomatosis. Peritoneal dialysis of four patients was stopped. All patients had catheter loss in 6-patient series of Szeto et al. ${ }^{(6)}$. Average age of these patients was 52 , and they had chronic glomerulonephritis $(n=5)$, and 
polycystic kidney $(n=1)$. One of 5 patients reported by Tzanetou K et al. ${ }^{(10)}$ had catheter loss. Baek et al. (5), reported a total of 5 cases including 2 patients with ESI and 3 patients with peritonitis, and 2 patients had catheter loss. Azak A et al. ${ }^{(11)}$, reported a single case, Beatriz Millan Diaz et al. ${ }^{(12)}$, reported single case, and N.Al-Hilali et al. ${ }^{13)}$ reported 4 cases.

S. maltophilia is known to be multi-drug resistant and is the reason of catheter loss in patients undergoing peritoneal dialysis. Being resistant to numerous drugs also makes it harder to select antibiotics. The organism was reported to be resistant to imipenem and meropenem from carbapenems, tobramycin and gentamicin from aminoglycosides, amoxicillin, clavulanic acid, a majority of cephalosporins (except for ceftazidime), quinolones, and numerous antipseudomonal penicillin ${ }^{(3,4,14,15)}$. In the study of CANWARD conducted between 2007 and 2011 in Canada, 22.746 clinical isolates were evaluated, $1.4 \%$ consisted of $\mathrm{S}$. maltophilia and in vitro activity for tigecycline was found to be good ${ }^{(16)}$. Different studies reported that the use of following combinations would create a synergistic effect: TMP-SMX and ticarcillin-clavulanate, TMP-SMX and ceftazidime, ticarcillin-clavulanate and levofloxacin, ticarcillinclavulanate and aztreonam, ceftazidime-ciprofloxacin $(17,18)$. IP treatment was changed to treatment with ceftazidime and TMP-SMX because resistance to empirically started cefazolin was also observed in our case. Additional systemic treatment with TMPSMX was started. However, systemic treatment was replaced with levofloxacin as culture-negativity could not be shown. Patient had thrombocytopenia (platelets $38.000 \mathrm{~mm}^{3}$ ) which was considered to develop in association with the drug treatment and then pancytopenia. Drug-associated thrombocytopenia may lead to mild to severe thrombocytopenia and it was also reported with fluoroquinolone group of drugs and recovery was observed when the drug was discontinued ${ }^{(19)}$. Thrombocytopenia of our case recovered as well by discontinuing medication (it was discontinued on the $10^{\text {th }}$ day of treatment). Bacterial growth was not observed in the culture at the end of treatment.

Differently from the cases in the literature, we additionally applied endoluminal brushing (EB) to our patient two times as the peritoneal fluid contained greater number of resistant cells. Biofilm layer occurring on the catheter in resistant and persistent peritonitis is known to have a crucial role. Antibiotic efficacy is considered to be decreased by reducing this biofilm layer via EB ${ }^{(20)}$. EB was successful for two of the three pediatric cases who had resistant peritonitis and were reported by us as a referral center and there was no loss of catheter. However, in none of these cases S. Maltophilia was grown ${ }^{(20)}$. Nevertheless, we think that EB should be tried as a part of treatment before removing catheter. But, we could not succeed with this case.

Consequently, S. Maltophilia is a microorganism whose infections lead to generally poor prognosis in patients undergoing chronic peritoneal dialysis. Immune dysfunction created by uremia, use of antibiotics and repetitive hospitalizations due to recurrent peritonitis pose a risk in these patients. Although ESI alone is less risky in terms of catheter loss, paying attention to resistance pattern of the microorganism while selecting an antibiotic should not be forgotten.

Conflict of Interest: None. Informed Consent: None.

\section{REFERENCES}

1. Lai $\mathrm{CH}, \mathrm{Chi} \mathrm{CY}, \mathrm{Chen} \mathrm{HP}$ et al. Clinical characteristics and prognostic factors of patients with Stenotrophomonas maltophilia bacteremia. J Microbiol Immunol Infect. 2004;37:350.

2. Al-Anazi KA, Al-Jasser AM. Infections Caused by Stenotrophomonas maltophilia in Recipients of Hematopoietic Stem Cell Transplantation. Front Oncol. 2014;4:232. [CrossRef]

3. Denton M, Kerr KG. Microbiological and clinical aspects of infection associated with Stenotrophomonas maltophilia. 
Clin Microbiol Rev. 1998;11(1):57-80. [CrossRef]

4. Lewis SS, Zaas A. Stenotrophomonas maltophilia. In: Sexton DJ, Bloom A, editors. UpToDate (2014). Topic 13961, version 8.0: pages: 1-8. Topic last updated: Jan 28, 2014.

5. Baek JE, Jung EY, Kim HJ, Lee GW, Hahm JR, Kang KR et al. Stenotrophomonas maltophilia infection in patients receiving continuous ambulatory peritoneal dialysis. Korean J Intern Med. 2004;19(2):104-8. [CrossRef]

6. Szeto CC1, Li PK, Leung CB, Yu AW, Lui SF, Lai KN. Xanthomonas maltophilia peritonitis in uremic patients receiving continuous ambulatory peritoneal dialysis. Am J Kidney Dis. 1997;29(1):91-5. [CrossRef]

7. Sanders CC, Sanders WE Jr. Beta-Lactam resistance in gramnegative bacteria: global trends and clinical impact. Clin Infect Dis. 1992;15(5):824-39. [CrossRef]

8. Dapena F, Selgas R, Garcia-Perea A, Del Peso G, Bajo MA, Fernandez Reyes MJ et al. Clinical significance of exit-site infections due to Xanthomonas in CAPD patients: a comparison with Pseudomonas infection. Nephrol Dial Transplant. 1994;9(12):1774-7.

9. Taylor G, McKenzie M, Buchanan-Chell M, Perry D, Chui L, Dasgupta M. Peritonitis due to Stenotrophomonas maltophilia in patients undergoing chronic peritoneal dialysis. Perit Dial Int. 1999;19(3):259-62. [CrossRef]

10. Tzanetou K, Triantaphillis G, Tsoutsos D, Petropoulou D, Ganteris G, Malamou-Lada E et al. Stenotrophomonas maltophilia peritonitis in CAPD patients: susceptibility to antibiotics and treatment outcome: a report of five cases. Perit Dial Int. 2004;24(4):401-4. [CrossRef]

11. Azak A, Kocak G, Huddam B, Işcan G, Duranay M. An unusual cause of continuous ambulatory peritoneal dialysisassociated outpatient peritonitis: Stenotrophomonas maltophilia. Am J Infect Control. 2011;39(7):618. [CrossRef]

12. Millán-Díaz B, González-Tabarés L, Cobelo-Casas C, López-
Vázquez M, Calviño-Varela J. Stenotrophomonas maltophilia: A rare cause of peritonitis in capd patients. Nefrologia. 2017 Jun 1. pii: S0211-6995(17)30091-7.

13. Al-Hilali N, Nampoory MR, Johny KV, Chugh TD. Xanthomonas maltophilia infection in chronic peritoneal dialysis patients. Scand J Urol Nephrol. 2000 Feb;34(1):67-9. [CrossRef]

14. Brooke JS. Stenotrophomonas maltophilia: an emerging global opportunistic pathogen. Clin Microbiol Rev. 2012;25(1):241. [CrossRef]

15. Falagas ME, Valkimadi PE, Huang YT, Matthaiou DK, Hsueh PR. Therapeutic options for Stenotrophomonas maltophilia infections beyond co-trimoxazole: a systematic review. J Antimicrob Chemother. 2008;62(5):889-94. [CrossRef]

16. Zhanel GG, Adam HJ, Baxter MR, Fuller J, Nichol KA, Denisuik AJ et al. Canadian Antimicrobial Resistance Alliance. Antimicrobial susceptibility of 22746 pathogens from Canadian hospitals: results of the CANWARD2007-11 study. J Antimicrob Chemother. 2013;68(Suppl 1):i7-22. [CrossRef]

17. Gülmez D, Cakar A, Sener B, Karakaya J, Hasçelik G. Comparison of different antimicrobial susceptibility testing methods for Stenotrophomonas maltophilia and results of synergy testing. J Infect Chemother. 2010;16(5):322-8. [CrossRef]

18. Liaw SJ, Teng LJ, Hsueh PR, Ho SW, Luh KT. In vitro activities of antimicrobial combinations against clinical isolates of Stenotrophomonas maltophilia. J Formos Med Assoc. 2002;101(7):495-501.

19. Cheah CY, De Keulenaer B, Leahy MF. Fluoroquinolone- induced immune thrombocytopenia: a report and review. Internal Medicine Journal. 2009;39:619-23. [CrossRef]

20. Aksu N, Yavascan O, Kara OD, Erdogan H, Kangin M. Does endoluminal brushing eliminate the need for catheter removal in peritoneal dialysis patients with persistent peritonitis? Adv Perit Dial. 2003;19:260-3. 